Available online at GSC Online Press Directory

GSC Biological and Pharmaceutical Sciences

e-ISSN: 2581-3250, CODEN (USA): GBPSC2

Journal homepage: https://www.gsconlinepress.com/journals/gscbps

(RESEARCH ARTICLE)

\title{
Effect of oregano (Oreganum syriacum L.) essential oil and cage density on performance parameters, egg quality criteria, some blood biochemical parameters, blood antioxidant capacity, and intestinal histopathology in laying hens
}

\author{
Mehmet Gül 1, ${ }^{*}$, Emre Yılmaz ${ }^{1}$, Gürkan Sezmiş ${ }^{2}$, Betül Apaydın Yıldırım ${ }^{3}$, Adem Kaya ${ }^{2}$ and Süleyman \\ Ercüment Önel ${ }^{4}$ \\ ${ }^{1}$ Ataturk University, Faculty of Veterinary Medicine, Department of Animal Nutrition and Nutritional Diseases, Erzurum, \\ Turkey. \\ ${ }^{2}$ Ataturk University, Faculty of Agriculture, Department of Feeds and Animal Nutrition, Erzurum, Turkey. \\ ${ }^{3}$ Ataturk University, Faculty of Veterinary Medicine, Department of Biochemistry, Erzurum, Turkey. \\ ${ }^{4}$ Hatay Mustafa Kemal University, Faculty of Veterinary Medicine, Department of Animal Nutrition and Nutritional \\ Diseases, Hatay, Turkey.
}

Publication history: Received on 10 November 2020; revised on 18 November 2020; accepted on 19 November 2020

Article DOI: https://doi.org/10.30574/gscbps.2020.13.2.0370

\begin{abstract}
Although many methods have been developed in order to reduce the negative effects in laying hens reared at high cage density, researches on effects of dietary supplementation of oregano (Oreganum syriacum L., OEO) essential oil as a feed additive to the diets are extremely sparse. This study investigated the effects of OEO and caging density on performance parameters, egg quality criteria, some blood biochemical parameters, blood antioxidant capacity, and intestinal histopathology of laying hens. We used 276 white Lohmann laying hens aged 38-40 weeks in the experiment. The animals were divided to positive control $\left(600 \mathrm{~cm}^{2}\right.$ hen/cage, $\left.\mathrm{PC}\right)$, negative control $\left(360 \mathrm{~cm}^{2}\right.$ hen/cage, NC), negative

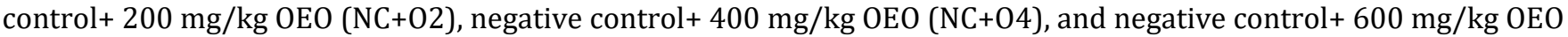
$(\mathrm{NC}+06)$. In this study, it was determined that egg weight and egg shell weight increased at higher caging density, but they did not change with dietary supplementation of OEO. In addition, the plasma calcium and phosphorus decreased with the higher caging density and dietary supplementation of OEO. Supplemented OEO to the diets of the laying hens reduced lipid peroxidation and improved antioxidant capacity and intestinal histopathology of laying hens. As a result, it was determined that OEO decreased the negative effects of high caging density. While this positive effect was found to be at a maximum dose at $400 \mathrm{mg} / \mathrm{kg}$ of OEO, it was determined that a dose of $600 \mathrm{mg} / \mathrm{kg}$ of OEO had a toxic effect, if even numerically.
\end{abstract}

Keywords: Caging Density; Duodenum; Egg; Laying Hens; Oregano.

\section{Introduction}

Egg production demand is constantly rising as increasing global population. As a result, the number of hen cages is increasing to meet the demand. However, an increase in the number of poultry cages has had a negative impact on economic efficiency because they can not be used effectively during periods of lower consumption and demand. Higher caging densities are one of the important stress factors that adversely affect poultry. The ideal caging area requirements has been estimated at a minimum $450 \mathrm{~cm}^{2}$ per adult hen [1]. Unfavorable caging conditions may adversely affect the laying hens' yield performance parameters, some blood biochemical parameters, blood antioxidation capacity,

\footnotetext{
* Corresponding author: Mehmet Gül

Ataturk University, Faculty of Veterinary Medicine, Department of Animal Nutrition and Nutritional Diseases, Erzurum, Turkey.
} 
intestinal histopathology, and certain physiological behaviors [2-8]. Although many methods and feedstuffs are used to reduce the negative effects of high caging densities in poultry [9-12], research on the specific effects of oregano/thyme essential oil is extremely sparse [13]. Oregano essential oil (OEO) is an essential oil derived from plants. Effects of OEO on poultry are variable. Previous studies have shown that it generally improved feed conversion ratio (FCR) and increases affect feed intake (FI), egg weight (EW), and egg production (EP) and but does not the damaged egg ratio (DER) $[14,15]$. But, there are studies that dietary supplementation of OEO does not effect on performance parameters in poultry [16-17]. Although there are study that indicate otherwise of this study [14], it has no effect on egg quality criteria such as the egg shape index (ESI), eggshell strength (ESS), eggshell thickness (EST), the albumin index (AI), the yolk index (YI), and the Haugh unit (HU) [15]. Like other essential oils, OEO has antioxidant properties. It generally decreases malondialdehyde (MDA) in poultry and also increases the plasma superoxide dismutase (SOD) and the plasma glutathione peroxidase (GPx) activities poultry $[16,18]$. However, no study has examined the antioxidative enzymes that the plasma catalase (CAT) and glutathione (GSH) in laying hens. Also, OEO is known to affect some blood biochemical parameters [15]. Studies on different types of oregano have found that it generally increases the villus height (VH), but does not have change the villus width (VW) and the crypt depth (CD) [17]. This study aimed determine whether dietary supplementation of OEO in laying hens can reduce the negative effects of higher caging density on the hens' performance parameters, egg quality, some blood biochemical parameters, blood antioxidant capacity, and intestinal histopathology.

\section{Material and methods}

Approval for this study was obtained from the Local Ethics Committee of Ataturk University (No:36643897-000E.1800064346).

\subsection{Essential oil, zeolite, and preparation}

The oregano herbs (Origanum syriacum L.) were collected in the season (autumn and winter) and dried in the shade for 3-4 days. The dried plant materials were chopped and placed in a beaker to obtain the essential oil using steam distillation. The components of the essential oil were identified using ISQ Single Quadrupole model gas (Thermo Fisher Scientific Inc., USA) chromatography (Table 1).

Table 1 Chemical Composition of Oregano (Origanum syriacum L.) Essential Oil

\begin{tabular}{|l|l|l|l|}
\hline Components* & Rate (\%) & Components* & Rate (\%) \\
\hline Alpha-Pinene & 1.30 & 3-Cyclohexen-1-ol & 1.27 \\
\hline Alpha-Thujene & 1.62 & Thymol & 18.38 \\
\hline Myrcene & 2.95 & Carvacrol & 18.23 \\
\hline Terpineol & 4.78 & & \\
\hline Caryophyllene & 2.21 & & \\
\hline Gamma-Terpinene & 21.89 & & \\
\hline P-Cymene & 17.90 & & \\
\hline 1-Octan-3-ol & 2.83 & & \\
\hline Trans-Sabinene hydrate & 2.04 & & 97.49 \\
\hline Total & \multicolumn{2}{|l}{} \\
\hline
\end{tabular}

The structure of each compound was identified using mass spectrophotometry with Xcalibur software [19]. The zeolite (clinoptilolite) used in the hens' diets was purchased from a commercial company (Rota Mining Corp., Turkey). The zeolite particle sizes ranged from 0.3 to $0.7 \mathrm{~mm}$. The lowest absorption potential of the zeolite was determined to be $40 \mathrm{~mL} / 100 \mathrm{~kg}$ [20]. Later, OEO was absorbed in zeolite $(0.15 \%)$ in 200, 400, and $600 \mathrm{mg} / \mathrm{kg}$ doses in beaker. Before being added to the hen' diets, oregano essential oil absorbed in zeolite was stored 24 hours at $+4^{\circ} \mathrm{C}$ in the fridge to minimize the volatility of its.

\subsection{Animals, diets, and management}

For the purpose of this study, 276 white Lohmann laying hens aged 38-40 weeks were used, kept in cages sized (Width: $59 \times$ Length: $61 \times$ Height: $60 \mathrm{~cm}$ ). The animals were divided into randomly 5 groups according to body weight (average, 
$1501 \pm 58.4 \mathrm{~g})$ including positive control $\left(600 \mathrm{~cm}^{2}\right.$ hen/cage, $\left.\mathrm{PC}\right)$, negative control $\left(360 \mathrm{~cm}^{2}\right.$ hen/cage, NC), negative control+ $200 \mathrm{mg} / \mathrm{kg}$ OEO (NC+O2), negative control+ $400 \mathrm{mg} / \mathrm{kg}$ OEO (NC+O4), negative control+ $600 \mathrm{mg} / \mathrm{kg} \mathrm{OEO}$ (NC+06). Standard feeder and drinker spaces were identical in each pen, and the animals were kept in 12-h light/dark cycles at a temperature of $24^{\circ} \mathrm{C} \pm 3^{\circ} \mathrm{C}$ [22]. Feed and water were supplied ad libitum and hens were fed on a soybean/maize-based diet. The animal experiment lasted 8 weeks and was preceded by a 7-day adaption period. AOAC [23] and Van Soest and Robertson [24] methods were used to determine the nutrient contents of the diets (Table 2).

\subsection{Performance parameters and egg quality criteria}

At the end of each week, the remaining feeds in front of animals were weighed to determine the FI. Egg samples were daily collected to calculate the EP and DER and also to measure the EW on a weekly basis. The FCR was calculated as the amount of feed consumed (in kg) per

Table 2 Nutrient Content and Ingredients of All Diets $(\mathrm{g} / \mathrm{kg})$

\begin{tabular}{|c|c|c|c|c|c|}
\hline \multicolumn{3}{|l|}{ Ingredients 6} & \multicolumn{3}{|c|}{ Analyzed nutrient levels ${ }^{6}$} \\
\hline & Control Group & Trial Groups ${ }^{3}$ & & Control Group & Trial Groups $^{3}$ \\
\hline Maize & 567.00 & 566.74 & DM \% & 88.55 & 88.70 \\
\hline $\mathrm{SBM}^{4}$ & 172 & 171.8 & $\mathrm{CP} \%$ & 17.50 & 17.47 \\
\hline Maize Gluten & 92.2 & 92.2 & $\mathrm{ME}^{2}$ & 12.17 & 12.15 \\
\hline Wheat Bran & 22.1 & 21.1 & $\mathrm{EE} \%$ & 5.48 & 5.47 \\
\hline Vegetable Oil & 36.4 & 36.5 & Ash \% & 19.48 & 19.51 \\
\hline Marble Powder & 88.85 & 88.82 & $\mathrm{CF} \%$ & 2.81 & 2.81 \\
\hline DL-Mehtionine & 0.71 & 0.72 & Сa $\%$ & 4.40 & 4.40 \\
\hline L-Lysine & 0.92 & 0.93 & Av. P \% & 0.37 & 0.37 \\
\hline $\mathrm{DCP}^{5}$ & 14.4 & 14.3 & & & \\
\hline Salt & 2.51 & 2.51 & & & \\
\hline Premix $^{1}$ & 2.91 & 2.91 & & & \\
\hline Zeolite & 0.00 & 1.50 & & & \\
\hline
\end{tabular}

${ }_{1}^{1}$ Per kg of feed: trans-retinol, $6000000 \mathrm{IU}$; cholecalciferol, $1200000 \mathrm{IU}$; dl- $\alpha$-tocopheryl acetate, $15000 \mathrm{mg}$; menadione, $2000 \mathrm{mg}$; thiamine, $1500 \mathrm{mg}$; riboflavin, $3500 \mathrm{mg}$; niacin; $12500 \mathrm{mg}$; d-pantothenate, $5000 \mathrm{mg}$; pyridoxine, $2500 \mathrm{mg}$; cobalamin, $7.5 \mathrm{mg}$; d-biotin, $22.5 \mathrm{mg}$; folic acid, $500 \mathrm{mg}$; choline chloride, $62500 \mathrm{mg}$; ascorbic acid, 25000 mg; Mn, 40000 mg; Fe, 30000 mg; Zn, 30000 mg; Cu, 2500 mg; Co, 100 mg; I, 500 mg; Se, 75 mg. 2 The value was calculated and converted, $\mathrm{MJ} / \mathrm{kg}$ (21). ${ }^{3}$ Experimental groups include all diets containing $0.15 \%$ zeolite. ${ }^{4}$ Soybean Meal. ${ }^{5}$ Dicalcium phosphate. ${ }^{6} \mathrm{~g} / \mathrm{kg}$

quantity of eggs (in kg). On days 7, 14, 28, and 56 of the treatment, one egg from each subgroup was randomly collected to determine the egg quality criteria. The ESS, ESI, EST, eggshell weight (ESW), yolk color (YC), AI, YI, and HU were determined as per the formulas used by Ergün et al. [25].

\subsection{Sampling and measurements}

At the end of the experiment, 5 hens that the average of the group in terms of body weight randomly selected from each treatment group (total 40 hens) and were slaughtered. Blood samples were collected into vacuum tubes anticoagulant to determine the lipid peroxidation, blood antioxidant capacity and some blood biochemical parameters. In order to obtain the plasma, the blood samples were centrifuged at $3000 \mathrm{rpm}$ at $4^{\circ} \mathrm{C}$ for $10 \mathrm{~min}$ and the plasma samples were stored at $-20^{\circ} \mathrm{C}$ until analysis. Plasma levels of malondialdehyde (MDA); activities of superoxide dismutase (SOD), glutathione (GSH), glutathione peroxidase (GPX), and catalase (CAT) were measured using Biotek $\mu$ Quant MQX200 Elisa Reader (Biotek Corp., USA) [26]. Blood plasma parameters were analyzed with a Beckman AU500 autoanalyzer (Beckman Coulter Inc., USA), and the hormones were analyzed with a Beckman Access 2 Immunoassay System autoanalyzer (Beckman Coulter Inc., USA). Intestinal samples obtained from them were fixed, waxed, and stained according to the method of Li et al. [27]. The VH, VW, CD, tunica mucosa width (TMW), and lamina propria (LP) were 
measured from samples selected from five different regions of the duodenum by the oculometer of a microscope equipped with a micrometer at 10x magnification.

\subsection{Statistical analysis}

Data were subjected to two-way ANOVA analysis procedure of SPSS 25.0 statistical program (SPSS Inc, Chicago, IL, USA) and the data are presented as mean \pm standard error. Significant differences were determined using Duncan's multiple range test. P-values less than 0.05 were considered as statistically significant.

\section{Results and discussion}

\subsection{Performance parameters}

In the study, it was observed that the EW increased in the groups with higher caging density. In addition, although it was observed that a numerical increase/improvement the FI, EP, FCR, and DER, there was no statistically significant difference among the groups for these parameters (Table 3). In studies carried out by Geng et al. [8] in laying hens, they were reported that although FI increased higher caging density, the EP, EW, and FCR were not affected by the difference caging densities. In the studies investigating the effects of higher caging density in poultry reported that although FI, EW, and EP decrease [6,7,28] and also DER increase [9], there are studies reporting that it has no effect [4,5,12]. The higher caging density in poultry causes to increasing of their activities (access to feed and water and also individual defense), and consequently, poultry spend more energy Al-Rawi et al. [2]. Cost of this energy is difficult to quantify because the types of activity is affected by many factors and it varies between 4-35\% [29]. The elevate in energy needs of poultry causes to increase of feed intake. In a study conducted by Leeson and Summers [30] in laying hens, EW was reported to be increased by elevated of cage density. The main reason for the enhanced in EW may be related the OEO intake of laying hens exposed to higher caging density. Although OEO has variable effects on performance in laying hens, it is know that usually does not affect performance parameters. In this study, it was observed that dietary supplementation of OEO had no effect on performance parameters except for EW in laying hens reared higher caging density. Similarly, Florou-Paneri et al. [14] found that 50 and $100 \mathrm{mg} / \mathrm{kg}$ of OEO had no effect on laying hens' FI, EP, or DER. Contrary to these study, was reported that increased FI [16,18] and EP [15] and also improved FCR with supplementation of oregano essential oil/oregano herb to the layer's chicken diets [18]. The cause of this difference may be associated with the extraction method and the amounts added to the diets as well as the procedure and duration of feed storage. Therefore, OEO may not be more effective in poultry exposed to stress.

Table 3 Performance parameters of all groups

\begin{tabular}{|l|l|l|l|l|l|}
\hline Groups & $\begin{array}{l}\text { FI } \\
(\mathbf{g} / \text { day })\end{array}$ & $\begin{array}{l}\text { EW } \\
(\mathbf{g})\end{array}$ & $\begin{array}{l}\text { EP } \\
(\mathbf{\%})\end{array}$ & $\begin{array}{l}\text { FCR } \\
(\mathbf{k g , f e e d / e g g})\end{array}$ & $\begin{array}{l}\text { DER } \\
(\mathbf{\%})\end{array}$ \\
\hline $\mathrm{PC}$ & 106 & $58.6^{\mathrm{b}}$ & 89.6 & 2.04 & 0.84 \\
\hline $\mathrm{NC}$ & 110 & $59.9^{\mathrm{a}}$ & 89.7 & 2.05 & 0.77 \\
\hline $\mathrm{NC}+02$ & 108 & $60.2^{\mathrm{a}}$ & 87.7 & 2.07 & 1.29 \\
\hline $\mathrm{NC}+04$ & 107 & $60.3^{\mathrm{a}}$ & 92.1 & 1.94 & 0.98 \\
\hline $\mathrm{NC}+06$ & 111 & $59.7^{\mathrm{a}}$ & 86.3 & 2.21 & 1.32 \\
\hline SEM & 1.64 & 0.32 & 2.69 & 0.06 & 0.35 \\
\hline$p$ & 0.232 & 0.047 & 0.617 & 0.111 & 0.722 \\
\hline
\end{tabular}

a,b: Statistical differences between different letters in the same column averages shown that it is significant (P<0.05). FI: Feed intake; EW: Egg weight; EP: Egg production; FCR: Feed conversion rate; DER: Damaged egg rate; SEM: Standard error means.

\subsection{Egg quality criteria}

Egg quality criteria are crucial for both egg producers and consumers. Poor quality causes major economic losses in the egg industry [25]. The effect of caging density and dietary supplementation of essential oils on egg quality criteria varies $[4,5,8,9,14]$. The effect of caging density in laying hens on egg quality criteria was indicated in Table 4 . In this study, it was observed that higher caging density had effect ESW. The results of this study, except for ESW are similar to Hayırl et al. [9], Kang et al. [5], and Geng et al. [8]. The formation of the egg shell is a long process that lasting 20 hours on average and occured more during the night times (especially during the last 14-16 hours). It was reported that hens receiving their daily supply of $\mathrm{Ca}$ in the afternoon, rather than morning, utilized significantly more of that day's dietary Ca for shell formation, excreted significantly less Ca via feces, and had significantly improved shell quality [31]. There is 
a negative relationship between Ca absorption from the digestive tract and Ca mobilization from bone during egg shell formation [32]. Due to the increase in the activity of NF-kB cells during stress, it was reported that more Ca mobilization from bone was achieved [33]. It was observed that supplementation of OEO in laying hen's diets did not affect the egg quality criteria (Table 4 ).

Table 4 Egg quality criteria of all groups

\begin{tabular}{|l|l|l|l|l|l|l|l|l|}
\hline Groups & ESI (\%) & $\begin{array}{l}\text { ESS } \\
\left(\mathbf{k g} / \mathbf{c m}^{2}\right)\end{array}$ & EST (mm) & ESW (g) & YC & AI (\%) & YI (\%) & HU \\
\hline PC & 72.2 & 4.79 & 0.370 & $6.56^{\mathrm{b}}$ & 10.4 & 8.01 & 42.7 & 77.3 \\
\hline NC & 73.9 & 4.57 & 0.361 & $7.03^{\mathrm{a}}$ & 10.5 & 8.38 & 42.5 & 78.2 \\
\hline NC+02 & 73.1 & 4.51 & 0.350 & $7.07^{\mathrm{a}}$ & 10.7 & 8.29 & 42.0 & 79.4 \\
\hline NC+04 & 73.6 & 4.87 & 0.359 & $7.23^{\mathrm{a}}$ & 10.4 & 7.81 & 41.3 & 78.0 \\
\hline NC+06 & 73.2 & 4.40 & 0.365 & $7.19^{\mathrm{a}}$ & 10.3 & 7.83 & 42.0 & 75.4 \\
\hline SEM & 0.53 & 0.17 & 0.01 & 0.11 & 0.20 & 0.44 & 0.63 & 1.94 \\
\hline$p$ & 0.250 & 0.333 & 0.357 & 0.001 & 0.799 & 0.838 & 0.637 & 0.687 \\
\hline
\end{tabular}

a,b: Statistical differences between different letters in the same column averages shown that it is significant $(\mathrm{P}<0.05)$.

ESI: Egg shape index; ESS: Egg shell strength; EST: Egg shell thickness; ESW: Egg shell weight; YC: Yolk color; AI: Albumin index; YI: Yolk index; HU: Haugh unit; SEM: Standard error means.

\subsection{Biochemical analysis}

Some blood biochemical parameters of laying hens exposed to the different caging densities are given in Table 5. Higher caging density negatively affected the plasma Ca and P While plasma Ca increased with the dietary supplementation (400 and $600 \mathrm{mg} / \mathrm{kg}$ ), plasma P increased with the dietary supplementation (200 and $600 \mathrm{mg} / \mathrm{kg}$ ). In this study, Chol, Trgl, AST, ALT, HDL, LDL, Ins, Glu, TP, Alb, and Crea was not affect by dietary supplementation of OEO. Although Asghar Saki et al. [3] reported that the blood calcium levels decreased in laying hens exposed to the higher caging density, there are also the study indicating that $\mathrm{Ca}$ and $\mathrm{P}$ increase [9].

Table 5 Plasma biochemical analysis results of all groups

\begin{tabular}{|l|l|l|l|l|l|l|l|l|}
\hline \multicolumn{2}{|l|}{ Groups } & PC & NC & NC+O2 & NC+O4 & NC+O6 & SEM & $p$ \\
\hline Chol & $(\mathrm{mg} / \mathrm{dL})$ & 86.8 & 83.8 & 103 & 98.3 & 87.8 & 8.08 & 0.406 \\
\hline Trgl & $(\mathrm{mg} / \mathrm{dL})$ & 1182 & 1244 & 1485 & 1205 & 1285 & 177.7 & 0.761 \\
\hline AST & $(\mathrm{U} / \mathrm{L})$ & 181 & 199 & 200 & 211 & 167 & 11.68 & 0.116 \\
\hline ALT & $(\mathrm{U} / \mathrm{L})$ & 2.75 & 3.25 & 7.25 & 2.5 & 4.5 & 1.89 & 0.413 \\
\hline HDL & $(\mathrm{mg} / \mathrm{dL})$ & 24.3 & 27.5 & 32.8 & 36.8 & 34.8 & 3.36 & 0.098 \\
\hline LDL & $(\mathrm{mg} / \mathrm{dL})$ & 42.8 & 42.5 & 41.6 & 52 & 42.8 & 5.48 & 0.659 \\
\hline Ins & $(\mathrm{uIU} / \mathrm{mL})$ & 0.35 & 0.51 & 0.53 & 0.44 & 0.59 & 0.07 & 0.189 \\
\hline Glu & $(\mathrm{mg} / \mathrm{dL})$ & 159 & 158 & 159 & 192 & 175 & 14.79 & 0.442 \\
\hline TP & $(\mathrm{g} / \mathrm{dL})$ & 4.43 & 4.9 & 5.76 & 5.78 & 5.55 & 0.39 & 0.249 \\
\hline Alb & $(\mathrm{g} / \mathrm{dL})$ & 1.53 & 1.6 & 1.68 & 1.59 & 1.53 & 0.06 & 0.563 \\
\hline Ca & $(\mathrm{mg} / \mathrm{dL})$ & $27.8^{\mathrm{b}}$ & $25.5^{\mathrm{c}}$ & $25.2^{\mathrm{c}}$ & $29.5^{\mathrm{ab}}$ & $32.9^{\mathrm{a}}$ & 1.13 & 0.05 \\
\hline P & $(\mathrm{mg} / \mathrm{dL})$ & $6.25^{\mathrm{ab}}$ & $5.30^{\mathrm{c}}$ & $6.70^{\mathrm{ab}}$ & $5.86^{\mathrm{bc}}$ & $6.93^{\mathrm{a}}$ & 0.38 & 0.043 \\
\hline Crea & $(\mathrm{mg} / \mathrm{dL})$ & 0.1 & 0.151 & 0.134 & 0.181 & 0.18 & 0.02 & 0.152 \\
\hline
\end{tabular}

a,b,c: Statistical differences between different letters in the same column averages shown that it is significant $(\mathrm{P}<0.05)$. Chol: Cholesterol; Trgl: Triglyceride; AST: Aspartate transaminase; ALT: Alanine transaminase; HDL: High density lipoprotein; LDL: Low density lipoprotein; Ins: Insulin; Glu: Glucose; TP: Total protein; Alb: Albumin; Ca: Calcium; P: Phosphorus; Crea: Creatinine; SEM: Standard error means.

In poultry, the absorption mechanism of phosphorus and calcium are interrelated and the absorption decreases if any of them disrupt balance [34]. It is thought that stress conditions may negatively affect the absorption of calcium and 
phosphorus by negatively affecting the intestinal villi properties [27]. There is no consensus yet about the effect of oregano essential oil on some blood biochemical parameters in poultry because it is quite variable. The results demonstrated that OEO improved bio-availability Ca and P in laying hens (Table 5). In a study of broiler chickens, it was observed that the increase in blood Ca and P was not statistically significant with the dietary supplementation of OEO [35]. In similar the study, Levkut et al. [36] stated that the blood Ca level increased with the dietary supplementation of OEO. However, it is reported that the ground thyme diets has an effect on blood Ca and P in broilers [37]. Thyme/oregano essential oil can positively effect on plasma Ca and P probably by improving intestinal morphology and oxidative stress or by increasing intestinal $\mathrm{pH}[16,38]$.

\subsection{Antioxidant enzymes and MDA level in the plasma}

Antioxidant enzymes plays an important role in protecting cells from damage caused by reactive oxygen species, but this process requires dietary supply of the appropriate nutrients [16]. Although higher caging density increased lipid peroxidation and deteriorate antioxidant capacity, OEO reduced lipid peroxidation and improved antioxidant capacity and intestinal histopathology in laying hens (Table 6). It was observed that the dietary supplementation (200 and 400 $\mathrm{mg} / \mathrm{kg}$ ) of OEO to the diets decreased plasma MDA. Moreover, plasma GSH levels were increased $400 \mathrm{mg} / \mathrm{kg}$ of OEO while it was decreased with $600 \mathrm{mg} / \mathrm{kg}$ of OEO. In laying hens consuming OEO, plasma SOD tended to increase in NC + $\mathrm{O} 2$ and $\mathrm{NC}+04$ groups and to decrease in $\mathrm{NC}+\mathrm{O} 6$ group. Although the plasma CAT increased with the dietary supplementation of OEO to the laying hens exposed to the higher caging density, it was found that the increase of GPx value only in the NC + 04 group was statistically significant. Similar to the study, in poultry, the higher caging density increased the plasma MDA [10,13], but the dietary supplementation of thyme reduced the plasma MDA [13, 39]. However, there are studies reporting that plasma MDA levels do not change with Oregano/thyme essential oil to diets [40]. In a study by Çetin and Güçlü [11] in laying hens, it is reported that the plasma SOD, CAT, and GPx enzymes decreased at higher density. The phytogenic product may improve the antioxidative status of poultry due to the antioxidant property of thymol and carvacrol by elevating the activity of antioxidant enzymes. It is reported that the addition of oregano and thyme essential oil to the feeds increased the activity of antioxidant enzymes included CAT, SOD, and GPx. It was suggested that the high antioxidant activity of thymol (a bioactive component presents in essential oil of oregano), is due to the presence of phenolic $\mathrm{OH}$ groups which act as hydrogen donors to the peroxy radicals produced during the first step in lipid oxidation, thus, retarding the hydroxy peroxide formation [16,38].

Table 6 Antioxidant enzymes activity and MDA level in the plasma of all groups

\begin{tabular}{|l|l|l|l|l|l|}
\hline Groups & $\begin{array}{l}\text { MDA } \\
(\mathbf{n m o l} / \mathbf{l})\end{array}$ & $\begin{array}{l}\text { GSH } \\
(\mathbf{n m o l} / \mathbf{l})\end{array}$ & $\begin{array}{l}\text { SOD } \\
(\mathbf{U} / \mathbf{l})\end{array}$ & $\begin{array}{l}\text { CAT } \\
(\mathbf{K U} / \mathbf{l})\end{array}$ & $\begin{array}{l}\text { GPX } \\
(\mathbf{U} / \mathbf{l})\end{array}$ \\
\hline PC & $7.53^{\mathrm{c}}$ & $2.51^{\mathrm{a}}$ & $61.8^{\mathrm{a}}$ & $85.7^{\mathrm{a}}$ & $1.63^{\mathrm{a}}$ \\
\hline $\mathrm{NC}$ & $14.0^{\mathrm{a}}$ & $1.82^{\mathrm{c}}$ & $56.8^{\mathrm{b}}$ & $67^{\mathrm{d}}$ & $1.46^{\mathrm{cd}}$ \\
\hline $\mathrm{NC}+02$ & $10.1^{\mathrm{b}}$ & $1.92^{\mathrm{bc}}$ & $60.8^{\mathrm{a}}$ & $81.0^{\mathrm{b}}$ & $1.52^{\mathrm{bc}}$ \\
\hline $\mathrm{NC}+04$ & $9.99^{\mathrm{b}}$ & $2.10^{\mathrm{b}}$ & $61.0^{\mathrm{a}}$ & $84.6^{\mathrm{a}}$ & $1.55^{\mathrm{ab}}$ \\
\hline NC+O6 & $13.2^{\mathrm{a}}$ & $1.22^{\mathrm{d}}$ & $48.8^{\mathrm{c}}$ & $73.1^{\mathrm{c}}$ & $1.41^{\mathrm{d}}$ \\
\hline SEM & 0.48 & 0.08 & 0.86 & 1.05 & 0.03 \\
\hline$p$ & $<0.001$ & $<0.001$ & $<0.001$ & $<0.001$ & $<0.001$ \\
\hline
\end{tabular}

a,b,c,d: Statistical differences between different letters in the same column averages shown that it is significant (P<0.05). MDA: Malondialdehyde; GSH: Glutathione-S-transferase; SOD: Superoxide dismutase; CAT: Catalase; GPx: glutathione peroxidase; SEM: Standard error means.

\subsection{Intestinal histopathology}

VH, VW, CD, LP and TMW are related to the migration, proliferation, and death of cells that are important for intestinal health $[17,41]$. The duodenum is the region where the absorption of nutrients occurs most in the intestine sections [42]. It is known that stress has an effect on intestinal morphology in hens [27]. In poultry, there are studies showing that the VH increased [10, 28, 43] and CD decreased [43]. There are also studies reporting that it obtained results supporting this study on, VH [10], VW [44], and CD [12, 45]. Findings show that VH, CD, LP, and TM were not affected by increasing the caging density, but higher caging density decreased VW (Table 7). To the best of our knowledge, previous studies that investigated the effect of caging density on laying hens' intestinal morphology has scarce. Li et al. [27] determined that different caging densities (12 and 16 hens $/ \mathrm{m}^{2}$ ) only affected VH in the ileum in $28^{\text {th }}$ day. It has been reported that in laying hens exposed to higher caging density, VH decreased in the ileum, while CD was not affected [27]. 
Other stress conditions effect also intestinal histopathology. In laying hens, VH increased and CD decreased with dietary supplementation of OEO. Also, TM value was found to be the highest in NC + 04 group. In a study on broilers, FonsecaGarcia et al. [14] found that 100, 200, and $400 \mathrm{mg} / \mathrm{kg}$ doses of OEO increased VH in laying hens. Mohiti-Asli and Ghanaatparast-Rashti [41] reported that $200 \mathrm{mg} / \mathrm{kg}$ doses of OEO in broiler' diets increased VH and decreased TMW.

Table 7 Intestinal histopathology of all groups

\begin{tabular}{|l|l|l|l|l|l|}
\hline Groups & $\begin{array}{l}\mathbf{V H} \\
(\mathbf{m} \boldsymbol{\mu})\end{array}$ & $\begin{array}{l}\mathbf{V W} \\
\mathbf{( m} \boldsymbol{\mu})\end{array}$ & $\begin{array}{l}\mathbf{C D} \\
(\mathbf{m} \boldsymbol{\mu})\end{array}$ & $\begin{array}{l}\mathbf{L P} \\
\mathbf{( m} \boldsymbol{\mu})\end{array}$ & $\begin{array}{l}\mathbf{T M} \\
\mathbf{( m} \boldsymbol{\mu})\end{array}$ \\
\hline $\mathrm{PC}$ & $1591^{\mathrm{b}}$ & $396^{\mathrm{a}}$ & $139^{\mathrm{a}}$ & 269 & $240 .^{\mathrm{b}}$ \\
\hline $\mathrm{NC}$ & $1512^{\mathrm{b}}$ & $238^{\mathrm{b}}$ & $139^{\mathrm{a}}$ & 228 & $233^{\mathrm{b}}$ \\
\hline $\mathrm{NC}+02$ & $2004^{\mathrm{a}}$ & $298^{\mathrm{b}}$ & $142^{\mathrm{a}}$ & 204 & $252^{\mathrm{b}}$ \\
\hline $\mathrm{NC}+04$ & $2033^{\mathrm{a}}$ & $259^{\mathrm{b}}$ & $132^{\mathrm{a}}$ & 257 & $334^{\mathrm{a}}$ \\
\hline $\mathrm{NC}+06$ & $2100^{\mathrm{a}}$ & $223^{\mathrm{b}}$ & $113^{\mathrm{b}}$ & 192 & $252^{\mathrm{b}}$ \\
\hline $\mathrm{SEM}$ & 91.71 & 26.15 & 5.93 & 22.33 & 15.59 \\
\hline$p$ & $<0.001$ & 0.001 & 0.016 & 0.108 & 0.001 \\
\hline
\end{tabular}

a,b: Statistical differences between different letters in the same column averages shown that it is significant (P<0.05).VH: Villus height; VW: Villus width; CD: Crypt depth; LP: Lamina propria; TM: Tunica muscularis; SEM: Standard error means

In stressful conditions, intestinal microbial ecology is disturbed, leading to dysbiosis Thymol and carvacrol maintain the intestinal mucosal integrity by reducing the total number of harmful bacteria, preventing adhesion to the epithelium, and decreasing the production of toxic compounds, thus improving absorption [27]. According to the findings, it was determined that the LP was not affected to increasing both caging density and OEO doses.

\section{Conclusion}

Consequently, the study showed that performance parameters, egg quality criteria, some blood biochemical parameters, blood antioxidant capacity, and intestinal histopathology in laying hens negatively affected by higher caging density. Although various feed additives are supplemented in order to eliminate the adverse effects of higher caging density, the use of oregano essential oil could be used more since they are both a natural resource and abundant in nature. With the supplementation of oregano essential oil to the diets of laying hens exposed to the higher caging density, while the performance parameters and egg quality criteria were not affected, plasma Ca and P increased. In addition, lipid peroxidation decreases and antioxidant enzymes increased and intestinal histopathology showed positively affected. Although this study is similar to other studies, it has different aspects. Although performance parameters, egg quality criteria, some blood biochemical parameters, blood antioxidant capacity, and intestinal histopathology has been observed to generally improve with supplementation of $400 \mathrm{mg} / \mathrm{kg}$ OEO to laying hens' diets, supplementation of 600 $\mathrm{mg} / \mathrm{kg}$ OEO to laying hens' diets generally has a toxic effect, even if numerically. Thus, more studies are required to determine the molecular mechanisms behind its effects and to better understand its effectiveness.

\section{Compliance with ethical standards}

\section{Acknowledgments}

This work was supported by the Scientific Research Projects Fund of Ataturk University under Grant number TSA-20186624.

\section{Disclosure of conflict of interest}

The authors declare no conflict of interest. 


\section{References}

[1] Dawkins, MS, Hardie, S. Space needs of laying hens. British Poultry Science. 1989; 30(2):413-416.

[2] Al-Rawi, B, Craig, JV, Adams, AW. Agonistic behavior and egg production of caged layers: genetic strain and groupsize effects. Poulty Science. 1976; 55(2):796-807.

[3] Asghar Saki, A, Zamani, P, Rahmati, M, Mahmoudi, H. The effect of cage density on laying hen performance, egg quality, and excreta minerals. Journal of Applied Poultry Research. 2012; 21(3): 467-475.

[4] Kang, HK, Park, SB, Kim, SH, Kim, CH. Effects of stock density on the laying performance, blood parameter, corticosterone, litter quality, gas emission and bone mineral density of laying hens in floor pens. Poulty Science. 2016; 95(12):2764-2770.

[5] Kang, HK, Park, SB, Jeon, JJ, Kim, HS, Kim, SH, Hong, E, Kim, CH. Effect of stocking density on laying performance, egg quality and blood parameters of Hy-Line Brown laying hens in an aviary system. European Poulty Science. $2018 ; 82$.

[6] Goo, D, Kim, JH, Park, GH, Reyes, D, Badillo, J, Kil, DY. Effect of Heat Stress and Stocking Density on Growth Performance, Breast Meat Quality, and Intestinal Barrier Function in Broiler Chickens. Animals. 2019; 9(3):107.

[7] Goo, D, Kim, JH, Choi, HS, Park, GH, Han, GP, Kil, DY. Effect of stocking density and sex on growth performance, meat quality, and intestinal barrier function in broiler chickens. Poulty Science. 2019a; 98(3):1153-1160.

[8] Geng, AL, Liu, HG, Zhang, Y, Zhang, J, Wang, HH, Chu, Q, Yan, ZX. Effects of indoor stocking density on performance, egg quality, and welfare status of a native chicken during 22 to 38 weeks. Poulty Science.2020; 99(1):163-171.

[9] Hayırlı, A, Esenbuğa, N, Macit, M, Laçin, E, Karaoğlu, M, Karaca H, Yıldız, L. Nutrition practice to alleviate the adverse effects of stress on laying performance, metabolic profile, and egg quality in peak producing hens: I. The humate supplementation. Asian- Asian-Australasian Journal of Animal Sciences. 2005; 18:1310-1319.

[10] Shakeri, M, Zulkifli, I, Soleimani, AF, o'Reilly, EL, Eckersall, PD, Anna, AA, Abdullah, FFJ. Response to dietary supplementation of L-glutamine and L-glutamate in broiler chickens reared at different stocking densities under hot, humid tropical conditions. Poulty Science.2014; 93(11):2700-2708.

[11] Çetin, E, Güçlü, BK. Effect of dietary l -carnitine supplementation and energy level on oxidant/antioxidant balance in laying hens subjected to high stocking density. Journal of Animal Physiology and Animal Nutrition. 2019; doi:10.1111/jpn.13210

[12] Kridtayopas, C, Rakangtong, C, Bunchasak, C, Loongyai, W. Effect of prebiotic and synbiotic supplementation in diet on growth performance, small intestinal morphology, stress, and bacterial population under high stocking density condition of broiler chickens. Poulty Science. 2019; doi:10.3382/ps/pez152

[13] Onel, SE, Aksu, T. The Effect of Thyme (Thymbra spicata L. var. spicata) Essential Oil on the Antioxidant Potential and Meat Quality of Japanese Quail Fed in Various Stocking Densities. Ataturk Universitesi Veteriner Bilimleri Dergisi. 2019; 14(2):129-136.

[14] Florou-paneri, P, Nikolakakis, I, Giannenas, I, Koidis, A, Botsoglou, E, Dotas, V, Mitsopoulos, I. Hen performance and egg quality as affected by dietary oregano essential oil and tocopheryl acetate supplementation. International Journal of Poultry Science. 2005; 4 (7):449-454.

[15] Radwan Nadia, L, Hassan, RA, Qota, EM, Fayek, HM. Effect of natural antioxidant on oxidative stability of eggs and productive and reproductive performance of laying hens. International Journal of Poultry Science. 2008; $7(2): 134-150$.

[16] Hashemipour, H, Kermanshahi, H, Golian, A, Veldkamp, T. Effect of thymol and carvacrol feed supplementation on performance, antioxidant enzyme activities, fatty acid composition, digestive enzyme activities, and immune response in broiler chickens. Poulty Science. 2013; 92(8):2059-2069.

[17] Fonseca-García, I, Escalera-Valente, F, Martínez-González, S, Carmona-Gasca, CA, Gutiérrez-Arenas, DA, ÁvilaRamos, F. Effect of oregano oil dietary supplementation on production parameters, height of intestinal villi and the antioxidant capacity in the breast of broiler. Austral Journal of Veterinary Sciences. 2017; 49(2):83-89.

[18] Roofchaee, A, Irani, M, Ebrahimzadeh, MA, Akbari, MR. Effect of dietary oregano (Origanum vulgare L.) essential oil on growth performance, cecal microflora and serum antioxidant activity of broiler chickens. African Journal of Biotechnology. 2011;10(32):6177-6183.

[19] Linskens, HF, Jackson, JF. Plant volatile analysis. Berlin: Springer; 1997. 
[20] Ulusoy, G, Albayrak, M. Mineralogical and technological properties of the zeolites from Foça (İzmir), Bigadiç (Balıkesir) and Gördes (Manisa). Maden Tetkik ve Arama Dergisi. 2009; 139 (139):61-74.

[21] Jurgens, MH. Animal Feeding and Nutrition. 8th ed. Dubuque IA: Kendall/Hunt Publishing; 1996

[22] Anonymous. Variety Lsl-Lite Commercial Management Guide. Cuxhaven, Germany; 2016.

[23] AOAC. Official methods of analysis. 16th ed. Washington, DC, USA: Association of Official Analytical Chemists; 1995

[24] Van Soest, PJ, Robertson, JB. Analysis of forages and fibrous foods. Ithaca: Cornell University;1985

[25] Ergün, A, Yalçın, S, Çolpan, I, Dikicioğlu, T, Yıldız, S. Figin yumurta tavugu rasyonlarinda degerlendirilmesi. Ankara Universitesi Veteriner Fakultesi Dergisi. 1987; 34:449- 466ny.

[26] Apaydin Yildirim, B, Ertekin, A, Kordali, S, Yildirim, S. Antidiabetic and antioxidant effects of Lupinus albus L. seed roasting ethanol extract in streptozotocin diabetic rats. World Journal of Advanced Research and Reviews. 2020; 7(2):007-016.

[27] Li, J, Miao, Z, Tian, W, Yang, Y, Wang, J, Yang, Y. Effects of different rearing systems on growth, small intestinal morphology and selected indices of fermentation status in broilers. Animal Science Journal. 2017; 88(6):900908.

[28] Chegini, S, Kiani, A, Parizadian Kavan, B, Rokni, H. Effects of propolis and stocking density on growth performance, nutrient digestibility, and immune system of heat-stressed broilers. Italian Journal of Animal Science. 2019; 18(1):868-876

[29] Balnave, D. Biological factors affecting energy expenditure. Energy Requirements of Poultry. British Poulty Science. 1974; 25.

[30] Leeson, S, Summers, JD. Effects of cage density and diet energy concentration on the performance of growing Leghorn pullets subjected to early induced maturity. Poulty Science. 1984; 63(5):875-882.

[31] Scott, ML, Hull, SJ, Mullenhoff, PA. The Calcium Requirements of Laying Hens and Effects of Dietary Oyster Shell Upon Egg Shell Quality. Poulty Science. 1971; 50(4):1055-1063. doi:10.3382/ps.0501055.

[32] Farmer, M, Roland Sr DA, Clark, AJ. Influence of dietary calcium on bone calcium utilization. Poulty Science. 1986; 65(2):337-344.

[33] Sheweita, SA, Khoshhal, KI. Calcium metabolism and oxidative stress in bone fractures: role of antioxidants. Current Drug Metabolism. 2007; 8(5):519-525.

[34] Keshavarz, K. Interaction between calcium, and phosphorus in laying hens. Nutrition Reports International. 1987; 36:9-20.

[35] Cengiz, SS, Yesilbag, D, Eren, M, Cetin, I, Meral, Y, Biricik, H. Effects of volatile oil additives on growth, carcass performances, and calcium and phosphorus concentrations in serum and bone of broilers. Revue de Médecine Vétérinaire. 2016; 167 (7-8):230-239.

[36] Levkut, M, Marcin, A, Revajová, V, Lenhardt, L, Danielovic, I, Hecl, J, Pistl, J. Influence of oregano extract on the intestine, some plasma parameters and growth performance in chickens. Acta Veterinaria. 2011; 61(2-3):215225.

[37] Hosseini, SA, Meimandipour, A, Alami, F, Mahdavi, A, Mohiti-Asli, M, Lotfollahian, H, Cross, D. Effects of Ground Thyme and Probiotic Supplements in Diets on Broiler Performance, Blood Biochemistry and Immunological Response to Sheep Red Blood Cells. Italian Journal of Animal Science. 2013; 12(1):e19. doi:10.4081/ijas.2013.e19

[38] Placha, I, Ocelova, V, Chizzola, R, Battelli, G, Gai, F, Bacova, K, Faix, S. Effect of thymol on the broiler chicken antioxidative defence system after sustained dietary thyme oil application. British Poultry Science.2019; $60(5): 589-596$.

[39] Büyükkılıç Beyzi, S, Konca, Y, Kaliber, M, Sarı̈zkan, S, Kocaoğlu Güçlü, B, Aktuğ, E, Şentürk, M. Effects of thyme essential oil and A, C, and E vitamin combinations to diets on performance, egg quality, MDA, and 8-OHdG of laying hens under heat stress. Journal of Applied Animal Research. 2020; 48(1):126-132.

[40] Ghazi, S, Amjadian, T, Norouzi, S. Single and combined effects of vitamin C and oregano essential oil in diet, on growth performance, and blood parameters of broiler chicks reared under heat stress condition. International Journal of Biometeorology. 2014; 59(8):1019-1024. 
[41] Mohiti-Asli, M., Ghanaatparast-Rashti, M. Comparing the effects of a combined phytogenic feed additive with an individual essential oil of oregano on intestinal morphology and microflora in broilers. Journal of Applied Animal Research. 2018; 46(1):184-189.

[42] Reece, WO, Erickson, HH, Goff, JP, Uemura, EE. Dukes' physiology of domestic animals. John Wiley \& Sons; 2015

[43] Sarica, Ş, Suiçmez, M, Çördük, M, Özdemir, D, Berberoglu, E. Effects of oregano essential oil supplementation to diets of broiler chicks with delayed feeding after hatching. Morphological development of small intestine segments. Italian Journal of Animal Science. 2014; 13:284-289.

[44] Sandikci, M, Eren, U, Onol, AG, Kum, S. The effect of heat stress and the use of Saccharomyces cerevisiae or (and) bacitracin zinc against heat stress on the intestinal mucosa in quails. Revue de Médecine Vétérinaire. 2004; 155:552-556.

[45] Burkholder, KM, Thompson, KL, Einstein, ME, Applegate, TJ, Patterson, JA. Influence of stressors on normal intestinal microbiota, intestinal morphology, and susceptibility to Salmonella enteritidis colonization in broilers. Poulty Science. 2008; 87(9):1734-1741. 